\title{
Research on Economic Trade Relations between Shaanxi and ASEAN under One Belt One Road Strategy
}

\author{
Xiaoyan Zhou ${ }^{1, \text { a }}$ \\ ${ }^{1}$ Xi'an International University, Xi'an, Shaanxi, 710077 \\ ${ }^{a}$ email
}

Keywords: One Belt One Road, Economic and Trade Relations; ASEAN and Shaanxi

\begin{abstract}
Under the strategy One Belt One Road, China and ASEAN in economic, political, and cultural exchanges have made great progress, more and more extensive cooperation. China One Belt One Road the proposed initiative is not only related to economic and trade development of China's provinces has a great role, also for the development of ASEAN countries also play a positive role and pragmatic results. Especially in the new international relations context, China's provinces and how to use their own advantages to actively integrate into the area all the way to the strategy, is the current focus. Between this, the paper Shaanxi Province, Shaanxi Province in the analysis based on the existing strategic advantage along the way on the current status of trade and economic relations with ASEAN, and detailed analysis of actual cases, the final analysis of Shaanxi future economic and trade relations focus on the development, hoping to provide valuable reference for the development of Shaanxi along the way to work.
\end{abstract}

\section{Introduction}

From the current status of cooperation between China and ASEAN regional point of view, not only the pace of development is accelerating, economic and trade relations between the two sides are deepening. ASEAN has become China's development strategy along the way during an important partner, but also an important way to achieve our business internationally [1]. In the area all the way to the strategic framework for strengthening economic and trade relations between ASEAN and Shanxi, Shaanxi become the Silk Road for the construction of the core area, and promote economic development in Shaanxi has a practical significance.

\section{The Advantages of Shaanxi Province in One Road One Belt Strategy}

Regional Advantage: Shaanxi in the northwest hinterland, across the middle Yellow River and Yangtze River Basin two connecting East China, Central China and an important hub for northwest and southwest. Province spanning the Yellow River, the Yangtze River two major rivers, are a large number of provinces of neighboring provinces, with the east and west of the regional advantages inherent.

Economic conditions Advantage: Overall analysis of economic developments in recent years in Shaanxi Province, Shaanxi Province in 2010 the total GDP ranks 16 (increased from 2005 20-2010 of 16), formally entered the Chinese "Wan one hundred million club province. Shaanxi total GDP 2012 year 1.445784 trillion yuan, representing a growth rate of 15.51 percent last year. faster than the national average of 6.2\%, ranking the first western in 2014, Shaanxi province GDP of 1.768994 trillion yuan, compared with last year an increase of 9.7\%; per capita GDP was 46,929 yuan annual investment in fixed assets 1.870969 trillion yuan [2] the province's urban residents per capita disposable income of 24,366 yuan;.. per capita disposable income of rural residents 7932 yuan in 2015, Shaanxi. GDP province 1.817186 trillion yuan, the growth rate of $2.72 \%$.

At present, Shaanxi Province has a national platform for cooperation open New West Ham, the Eurasian Economic Forum, Xi'an National E-commerce cross-border trade service pilot cities. New West Ham which belong to the national New Area, the state in this regard not only to give policy support, but also as a focus on the development of urban, open it as an important hub of the west, the new engine of western development. Shaanxi Silk Road which has namely China International 
Fair for Cooperation between East Investment and Trade Fair has become the central and western sound interactive mechanism for cooperation to strengthen brand exhibition and national level show business communication of a national nature. Euro-Asia Economic Forum to promote the central and western China and Central Asia, Russia and other countries to establish a comprehensive, multi-level communication and cooperation platform channel [3]. Plus relying on Xi'an Comprehensive Bonded Zone, Shaanxi Province has now being gradually build a medium for the Silk Road between Asia and Europe.

\section{Research Status of Economic and Trade Relations between ASEAN and Shaanxi under the Strategy Of One Belt One Road}

With China - ASEAN Free Trade Area to accelerate the pace of construction, China and ASEAN countries to enhance mutual political trust being, also deepen economic integration. China-ASEAN bilateral trade has been growing steadily, in 2013 bilateral trade in goods amounted to \$ 443.6 billion, an increase of $10.9 \%$. At present, China is the largest trading partner of ASEAN, ASEAN is China's third largest trading partner and fourth largest export market and second largest source of imports.

October 23, 2014, in Shaanxi Province's "Marine Silk Road and ASEAN will promote new business opportunities", the Shaanxi nearly more than 100 companies have said very bullish on China - ASEAN Free Trade Area of new business opportunities. Shaanxi variety of mechanical and electrical products, fruits, halal products sold in ASEAN countries, more and more Shaanxi enterprises have gradually accelerated pace of investment in ASEAN. According to Customs statistics show that in Xi'an, Shaanxi Province in 2014 the total value of import and export trade of Singapore \$ 227 million, an increase of 1.5 times, which exports \$ 038 million, an increase of 8.4\%; imports 189 million US dollars, an increase of 2.4 times. Under the strategy One Belt One Road, not only bring economic growth to the relevant countries along the Silk Road city, while achieving closer economic ties to Europe and Asia countries, mutual cooperation and development provides a good condition.

ASEAN strategic area along with Shaanxi mutual investment and economic and technological cooperation has been extended

The 18th session of the Western Fair cum Sibo were invited to 77 countries and regions, 674 delegations, 1,800 exhibitors participating foreign guests; organize investment negotiations docking activities 29 games, Central Asia, the Baltic region and Central and Eastern Europe, India, Nepal, Russia, Italy and other countries and regions also held a special investment and trade promotion activities. Shaanxi foreign-funded projects were signed contracts with a total investment amount of \$ 4.656 billion; domestic joint projects signed contracts with a total investment amount of 613.278 billion yuan; high-tech achievements turnover of 16.526 billion yuan contract. Delegation of each province were signed contracts of foreign investment projects with a total investment $\$ 5,067,000,000$; domestic joint projects signed contracts with a total investment amount of 895.658 billion yuan.

"Chang'an" westbound train current total of 162 courses open line, which opened in 2015 line 95 classes. Trains had moved from one class per month to the initial operation is now normal Operation 2-3 classes per week. Cumulative transport cargo weighing a total of 282,000 tons, worth about \$ 290 million export cargo category covers industrial raw materials, machinery and equipment, industrial spare parts, building materials, food, light industry products, such as the six major categories, a total of 206 species. Sourcing mainly from Shaanxi, Gansu, Ningxia, Shandong, Jiangsu, Hebei, Shanghai, Zhejiang, Shaanxi, where local supply about $30 \%$, about $70 \%$ of the field supply, opening up and becoming Xi'an called out to do real "area all the way to "new starting point for the beautiful cards. Cargo destination sites across 44 cities and five countries in Central Asia Kazakhstan.

One Belt One Road the narrow ASEAN strategic interconnection with Shaanxi more frequent and in-depth

November 28, 2013, Xi'an to Almaty Central Asian international freight trains "Chang'an" 
officially open the line, marking the first time in Kazakhstan exports to China inland transportation commodity successful completion of the journey, and Kazakhstan cooperation capacity, particularly in the agricultural cooperation has taken new steps.

At the Fifth Euro-Asia Economic Forum, formed along national consensus to jointly promote the organization to establish friendly relations with Mare, Turkmenistan, Uzbekistan, Samarkand and other cities and carry out exchanges and cooperation. China has in the "energy base," said Yulin City, 7 over $\$ 10$ billion construction project is under preparation. In addition, Shaanxi Province has set up more than 300 overseas companies and foreign institutions, investment mainly in Thailand, the United States, Hong Kong and other 48 countries and regions, more than design equipment manufacturing industry, real estate development, wholesale and retail.

\section{Case Study of Economic and Trade Relations between ASEAN and Shaanxi under the Strategy Of One Belt One Road}

November 2002 China - ASEAN Free Trade Area agreement was signed, the establishment of the free trade zone with the EU at the time, called the world's three NAFTA economic cooperation zone. At that time China has a clear understanding of the important role of our country in Southeast Asia to develop export-oriented economy [4]. October 2011, Malaysian Prime Minister Najib Tun Razak said the establishment of a free trade area for trade between ASEAN and China has a great role in promoting contacts, coupled with our proposed strategy along the way, to inject again advantageous bilateral cooperation force, in line with the interests of each country in Southeast Asia.

Shaanxi full play to the east and west of the geographical advantage, all the way to the docking area of the proposed scheme focus on building "five centers", including integrated transport hub, logistics center of international trade, science, education, cultural tourism, energy and financial center, the center of economic and trade cooperation, We hope to further promote the development of Shaanxi.

By leveraging the advantages of Shaanxi detail transportation hub, to build a transport and logistics hub, Xi'an Silk Road economic belt build the largest logistics distribution center. The other is learning innovation system Shanghai FTA customs supervision, the establishment (Xi'an) free economic zone in Shaanxi. Promote cooperation between Shaanxi and park construction Korea Industrial Cooperation Park, China and Russia and Central Asia, to create a feature international industrial park.

With the deepening of bilateral cooperation in 2010, ASEAN has become the third largest trading partner in Shaanxi [5]. 2010-2012, Shaanxi and ASEAN trade cooperation to achieve 10\% -15\% in the total foreign trade in Shaanxi Province. Shaanxi Province in 2013 import and export trade with ASEAN countries, Singapore is the first volume of bilateral trade reached \$ 1.1 billion, an increase of 26.2\%, followed by Malaysia, the trade volume was \$ 231 million, a third of Thailand, for the trade \$ 220 million.

Both sides in the process of constant development in Shaanxi with Singapore, Malaysia, Thailand, Indonesia and other ASEAN countries have established investment partnerships, involving multiple industries industrial equipment manufacturing, wholesale and retail. Singapore's investment in Shaanxi, which has more than 1.8 billion US dollars, a total investment of Shaanxi in Singapore amounted to \$20 million [5]. The two sides signed the contract amount reached \$ 362 million. Thai investment in Shaanxi Province has more than 65, more than 110 million US dollars of investment, including Shaanxi Province, Northwest Rubber Group, Shaanxi heavy truck enterprises to invest in Thailand, more than 120 million US dollars.

\section{Development Key Points of Economic and Trade Relations between ASEAN and Shaanxi under the Strategy Of One Belt One Road}

On the basis of the existing development, Shaanxi next focus is the construction of the Silk Road economic belt an important fulcrum, and has become an important hub opening to the West. Speeding up the construction of the Silk Road economic belt at the same time, strengthen 
cooperation with resource exploration and development in the field Central Asian countries, Australia and other countries, to build national aviation City Experimental Zone, Shaanxi Province, to promote energy resource center located in financial and trade center, to encourage various enterprises to actively participate in the development of New West Ham among actively support the establishment of a New West Ham its three-dimensional integrated transport system. The provincial capital of Xi'an to build a Silk Road economic belt manufacturing center, transportation, communications center, the center of trade and economic cooperation, energy and financial center, science and technology education centers and cultural tourism center.

\section{Conclusion}

Along the way, as a long-term strategy, transnational objectives, requirements and investment between China and ASEAN to strengthen support for many aspects of policy, funding and manpower in this regard. Shaanxi Province and the main task is to give full play to their advantages and actively participate in the economic corridor to the north line of construction, and the ASEAN countries to expand trade and investment more in-depth cooperation with ASEAN to achieve mutual benefits.

\section{References}

[1] Guo Kewei. Institute of Finance and Commercial Bank of China for the Chinese cities "along the way" under the Grand Strategy. - ASEAN Trade Status and Opportunities [N] China Economic Times, 2015-01-09004.

[2] Zheng Zhilai. Study to eastern and western provinces "along the way" development strategy and cooperative path [J]. Contemporary Economic Management, 2015, 33 (07): 44-48.

[3] Yin Liying. Not holding Zhao Wei Ming regional cooperation and route "Silk Road Economic Belt" interoperability - Taking Shaanxi Province [J]. Chinese Economic Circulation, 2015,21 (08): 75. -80.

[4] Cao Li. from the economic and trade cooperation to see key directions and breach of Guangxi "along the way" construction [J]. Guangxi Economic, 2015, 17 (06): 47-48.

[5] Zhang Zhuqun. The ancient Silk Road," the contemporary geopolitical, economic upgraded version - the research literature on "along the way" of [J]. Yunnan Geographic Environment Research, 2015, 33 (04): 7-14.

[6] Xu Shaoshi. coordinate domestic and international situations strategic choice - depth study and General Secretary Xi important expositions on "along the way" strategic concept [J]. Chinese trade Tribune, 2015,52 (30): 4-7. 